SECURITY PROBLEMS : AN AFRICAN PREDICAMENT

by

His Excellency, Francis M. Deng

Sudan Ambassador to Canada

Thirteenth Annual

Hans Wolff Memorial Lecture

October 23, 1981

\author{
African Studies Program \\ Indiana University \\ Bloomington, Indiana \\ 1981
}


Copyright 1982

by

African Studies Program

Indiana University

ISBN : $\quad 0-941934-36-5$

Library of Congress Catalog Card Number: 81-71701 


\section{HANS WOLFF}

1920-1967

Hans Wolff was born on April 6, 1920 in Mainz, Germany. In 1934 his family went to Spain where he remained until 1937 when he immigrated to the United States. He attended Queens College, New York from 1939-1941 and then transferred to Indiana University. From 1942-1946 he served with the Military Intelligence Corps. After the war he returned to Indiana and in 1946 obtained the B.A. magna cum laude in Linguistics. In 1947 he was awarded the M.A. in Linguistics and in 1949 a double doctorate in Anthropology and Linguistics (one of the first to be given by that department). In 1949 he was appointed to the faculty of the University of Puerto Rico where he taught for eleven years. His early work was in Amerindian languages, especially in Siouan studies, and in the teaching of English as a second language. While still at the University of Puerto Rico, he was invited in 1953 to visit Nigeria, and from that time his interest in Africa and African languages grew. He published widely on the languages and language problems of Nigeria and at the time of his death was one of the leading authorities on Yoruba. In 1960 he accepted an appointment at Michigan State University in the African Studies Center where he taught for three years. While at Michigan State he helped to found and to edit the Journal of African Languages. He also assisted in the early development of the West African Language Conference and for several years served as Chairman of the African Linguistics Committee of the African Studies Association. At the time of his death in September 1967, he was Professor of Linguistics at Northwestern University. 


\title{
SECURITY PROBLEMS: AN AFRICAN PREDICAMENT
}

\author{
His Excellency, Francis M. Deng
}

Sudan Ambassador to Canada

\section{The Stand Point}

Before entering the subject matter of my address to this very distinguished group of intellectuals and scholars, I should perhaps clarify my standpoint. When I was appointed to my first diplomatic post as Ambassador to the Scandinavian countries, an academic friend advised me not to remain in diplomacy for more than three years. I am afraid it has been nearly 10 years since. And it was not to be long before I was to have some idea of the time-limit he placed on my diplomatic experience, for in Sweden I encountered an incident which was by no means flattering to diplomacy. I had been invited to give a talk to a society of intellectuals. As we sat waiting for the meeting to start, my host apologized for not having mentioned my diplomatic title in the invitations and in the announcement, adding, "You see, most Swedes think Ambassadors are very boring."

Well, all I want to say is that I am not here to deliver a scholarly message, but I would not want my talk to be taken as a diplomatic speech either. I hope to be open and candid, perhaps a little more than is conventional in diplomacy.

\section{The Problem}

When I received the invitation to address this meeting, I wondered what I should talk about and a wide variety of subjects recommended themselves. I have only recently chosen to talk on the security problem in Africa, partly because it is increasingly a topic of discussion in African-American circles and also because our part of Africa has very much been in the news lately, a fact which might have driven me into avoiding the topic, but which has added to my desire to face the challenge.

The security problem in Africa is a manifestation of yet another critical phase in the political evolution of the continent. During the fifties and sixties, the people of Africa were united by their common struggle against foreign domination. The overriding goal was total independence from 
colonialism and the enemies were the foreign powers who were seen as not only dominating the people of Africa, but also exploiting the continent to their unfair advantage. While the situation in Namibia and South Africa remains a painful thorn in the African flesh, the process of decolonization is nearly complete and the challenges of nation building are replacing the struggle for liberation. Unfortunately, the issues of nation-building are less clear-cut: the goals are not so well defined; the obstacles are less obvious; the identities of the enemies are blurred; and the whole process is a lot more intricate and complex.

Nkrumah had promised that once the political kingdom was attained, the rest should flow. The leaders of independent Africa soon saw their real enemies as ignorance, poverty and disease. Some viewed the problem in economic terms; others in cultural terms; and yet others blamed these afflictions on neo-colonialism and the subtleties of remote controls and continued foreign domination. While the rhetoric continued against foreign exploitation in one form or another, there evolved an increasing realization that interdependency was perhaps a more accurate way of describing postindependence relations with the former colonial powers and other nations and peoples of the world. Some form of cooperation rather than confrontation became the theme. Efforts in this direction continue and despite the increasing difficulties in the North-South dialogue, the tone has been set. Greater emphasis is increasingly being placed on defining the mutuality of interests underlying international cooperation.

Perhaps one of the most critical developments in this process has been the extent to which internal differences, tensions, and conflicts surfaced once the common bond of the common struggle against a common enemy was loosened by the achievement of independence. The assumption of political power by the nationals was initially viewed in collective terms, not dissimilar to economic statistics of gross national product which do not specify. who gets what from the produce. Once the breakdown was made, inequities became apparent, and just as gross-statistical affluence does not gratify the poor, collective independence that gave power to a faction did not end the liberation struggle; it only changed the identities 
of the conflicting parties. It is then that internal diversities and disparities began to manifest themselves and undermine the sense of unity, of national identity, and of a common purpose in nation-building. Then follows an internal strife, expressed at various levels, often resulting in frequent changes of governments through revolutions, coups and counter-coups. This may extend beyond the domestic confines to generate tensions between nations, exploding in violence and regional hostilities. The scope of these conflicts has unfortunately gone beyond the continental scene, entailing a new form of dependency on foreign powers, especially in the critical field of military assistance. The bonds with foreign powers may be ideological or purely pragmatic, the crucial factor being the readiness to deliver the goods or having a common enemy. The more foreign intervention has increased, the greater the reaction of the African countries against foreign intervention as a matter of principle. But the reality remains a pervasive resort to foreign intervention.

It was at the OAU Summit at Libreville in 1977 that the African Heads of State pronounced themselves against what they viewed as the grave issue of foreign intervention. But since then, far from abating, the problem has intensified as one area after another has found itself in regional conflicts that have attracted foreign intervention. The cycle between regional tension, conflict and intervention has been reinforced, for these evils breed on one another.

\section{The Root Causes}

Events of this gravity and magnitude do not just occur in a senseless way, for the consequences are too severe to be taken lightly by all concerned. One must assume that there is some explanation somewhere, however much we may disagree on the soundness of the grounds. What are the root causes of the tensions, the turmoil, and the conflicts that plague the domestic and regional scene of independent Africa? What are the motives of the conflicting parties? What compels African nations to resort to foreign powers for military intervention even at the risk of compromising, if not endangering, their hard-won independence? And what moves foreign powers to respond positively at the grave risk of getting themselves engulfed in armed conflict away from their boundaries? And 
if Africans reject dependency on foreign powers, how else do they tackle the formidable problems that compel them to resort to foreign powers?

of course, I am not so presumptuous as to claim that I have answers to these questions, but I would like to go a Iittle deeper into an angle which I believe is quite pertinent. I begin my analysis with the premise that issues of peace and security are domestically rooted, but that the domestic scene cannot be seen in isolation from regional and international dynamics. A cursory look at the African scene will reveal that complex trends have generated diversities and disparities that provide fertile soil for confrontation and conflict. Africa has experienced a process of fusion and fission that many consider to be part of the colonial designs of unite and divide and rule, but which the colonizers themselves defend as recognition of existing realities and protection of the weaker partners in the newly established system of nation state. Boundaries between and within these entities were artificially conceived and effected to sever the ties of kith and kin. New identities were fostered that maintained and even reinforced alienation and disintegration. As a result of racial, cultural and religious manipulations, a mutually hostile view was fanned and developed into a sophisticated political stand. During the struggle for independence, these differences were secondary and were overshadowed by the common cause, but the removal of the common enemy soon elevated them to the front-line of divisive national issues.

Colonial experience and the advent of the modern nation state also invaded the traditional African egalitarianism with European concepts of political, social and economic stratification. New educational, economic, social and cultural opportunities were offered with striking consequences that deepened the new concepts of stratification. These diversities and disparities provided nursing grounds for political factionalism and power struggle. As between countries, the problems became manifest in the anomalies and sensitivities of artificial boundary demarcations. The result of these power struggles and border confrontations is actual or potential hostility. To meet the challenge, the parties concerned need weapons. Weapons need financial means and 
expertise, often lacking or inadequate. So, the poor nations of Africa get into heavy debts and experts become essential parts of the weapons. Should the exigencies demand, troops are requested and flown in. Then African nations fall back into the intractable web of dependency.

The scene is further dramatized in political, economic and humanitarian terms by the great influx of refugees across the anomalous borders of neighboring countries, an influx which gives Africa by far the largest share of the refugee population of the world. Because of the humanitarian attitude implicit in African family and tribal values, and also because of the kinship ties which transcend the boundaries of the nation-states, these refugees are generally well received, treated with hospitality, and accepted into the social and economic fabric of the host countries. While this favours the African refugees over refugees in other parts of the world, it has also tended to conceal their tragedy and minimized international response to their needs. Their integration into the recipient countries, sharing the little there is, has added to the magnitude of the problems which these countries face. But in political terms, the influx of refugees across the borders often implies extending the domestic problems of one country into another, especially as some of the refugees continue to harbour political ambitions against their adversaries back home. The recipient countries may happen to share the political aspirations of the refugees or at least sympathize with them and lend a helping hand in promotion of their cause. The result is a vicious cycle of complications and aggravations.

The charter of the OAU and the principles governing the organization appear to be contradictory and offer everyone some ground for justifying their conduct. The principle of self-determination appears in conflict with the principle of maintaining inherited boundaries. Consequently, supporting the right of self-determination for a subject people implies interference in the affairs of others. And often, the principle of peaceful solutions to problems becomes only a slogan. Before the Sudan offered a workable alternative by reconciling these principles through a negotiated settlement and the granting of autonomy to the South, the principle of maintaining the boundaries was considered so sacrosanct that even a genuine 
grievance of a minority people was totally disregarded. Internal suffering and subjugation were overshadowed by the principles governing the boundaries and forbidding interference in the domestic affairs of others.

While deploring foreign presence in Africa, the Organization of African Unity recognizes the right of any country to invite any power, African or foreign, to intervene and assist the inviting country with its security problems. This is viewed as falling within the sovereign right of any state, especially as foreign intervention is usually seen as a matter of necessity or survival.

Of course, the subjectivities of the states concerned are vital to their felt needs, but it would be wrong to place the motivation of all the states on equal par. Some are motivated by ideological missionary zeal; others have territorial ambitions in disregard to the colonial boundaries or the accepted principles of the OAU; yet others are motivated by dreams of greater unity, which they believe would be facilitated by overthrowing uncooperative regimes and replacing them with more agreeable ones; and yet others are primarily reacting to the threats and dangers they see in the attitude of other states. Put in other words, some are more agressive than others while others are defensive in their reaction.

The motivations of the aiding foreign countries also differ. Some are economically motivated to acquire or maintain access to Africa's raw materials, including the vast resources still to be tapped and utilized; others are driven by strategic imperatives and ideological rivalry; implicit in the strategic or ideological race for military power is the accumulation of weapons that become outmoded in rapid succession and for which a purpose or a market must be found; others combine all these motives with the strategic move to fill a vacuum which they believe is created by the withdrawal of colonial powers. This last point is of especial importance and calls for deeper reflection.

When I was Ambassador to Washington, I attended a meeting between the African Ambassadors and the then Secretary of State, Henry Kissinger. The issue for discussion was U.S. African 
policy. Dr. Kissinger found the meeting to be an opportunity for voicing American unhappiness with the critical attitude of the Africans against the United States and their contrasting approving attitude towards the Soviet Union. According to Kissinger, whatever the United States did was viewed as wrong and whatever the Soviet Union did was accepted as right. In his own words, "It is statistically impossible for the United States to be always in the wrong." A similar complaint was often voiced to me by Senators and Congressmen and I must say that I was so sympathetic to the arguments that I have often quoted them in my talks and discussions.

But I also offer my American friends an explanation which at least, distributes the responsibility for this oversimplification. There is no doubt that until recently the main preoccupation of Africa was liberation from colonialism and although the United States has been a catalyst in the decolonization process, the enemies of the liberation struggle were allies whose interests were viewed as inherently bound together with those of the United States. The U.S. found itself in something of a dilemma. On the one hand, the very foundation of the United States stood out as a conspicuous symbol of the Independence Movement, with all it implies of freedom, liberty and equality. The motivations of the Africans' rise against colonialism were not too different from those that drove the Americans two hundred years ago to rise against Britain. This fact presumably prompted the United States to initially champion the world-wide move for independence, following the Second World War. On the other hand, it was not easy for the Americans to take sides with the adversaries of their allies and disregard their mutual interests. The result of these paradoxes was an ambivalent relationship with Black Africa. While not vocally opposing, but indeed endorsing the African move for independence, the United States did not show active support for the liberation struggle, an attitude which the Africans identified with that of the imperial powers.

In sharp contrast to the United States and her European allies, the Soviet Union and other countries of the Communist bloc took the obvious alternative, unequivocally identified themselves with the colonized peoples of Africa, and worked actively to support their struggle for independence. 
This complicated the picture of African-American relations and made the struggling Africans appear communistinspired opponents of the United States. But as Africa began to score victories and liberate itself, the political strategy of the United States in the fifties and the sixties was to strengthen those African regimes which they felt would assist in their containment of communism. Cold war political objectives and access to military facilities weighed heavily in the selection of recipient countries. But the more the United States worked to strengthen regimes against communism with 1ittle or no regard to the interests of the masses, the more these regimes grew unpopular, the more the United States became resented, and the more the vicious circle perpetuated itself.

In the face of these deeply rooted biases, many African countries initially tended to be aligned towards the socialist bloc even as they pronounced themselves dedicated to the principles of non-alignment. This is the attitude Henry Kissinger and congressional representatives complained about.

The picture has gradually begun to change. An increasing number of African countries have come to realize that the weapons needed for the war of liberation are not the same as the weapons needed for peace-time reconstruction and nation-building. These countries are unveiling the elements of foreign interference, dependency, and even domination in the attitude of those powers who initially appeared to have an altruistic desire to aid the African liberation struggle. Some countries have gone as far as realizing that these exposed self-seeking motives are perhaps more dangerous in the long run than the over-stated interests of the United States and the Western world against Communist expansionism.

A sense of history and an explanation of past attitudes remains necessary to facilitate a better understanding and appreciation of one another and of the mutual interests at stake in the face of a more subtle but perhaps more dangerous threat from the opposing bloc. It does not help to be resentful of the critical attitude of Africa without asking how such an extreme prejudice has evolved. To understand is to appreciate and hopefully to remedy the causes of the mutual prejudices.

IV. Sudan's Experience 
Now, I would like to say a word about the experience of the Sudan with respect to the issues I have raised.

Because of the domestic foundations of security problems in Africa, it is often said with justification that the best way for any government to ensure internal security is to put its house in order, to serve the interests of its people to a pacifying level of satisfaction, and to sustain a degree of national consensus behind government policies, programmes and actions. Sudan offers a good example of both the validity of this argument and the limitations of domestic efforts in the face of problems imposed from outside the country and the continent.

Sudan is typical of the problems of diversity and disparity which characterize many countries of Africa. The complex Afro-Arab realities of the country, which are true even of the North alone, were molded and manipulated to the point where the country was reduced to the simplistic labels of Arab North and Negroid South. Here I must pause to tell a favorite story of mine which illustrates this point. A Southern Sudanese came to study in the United States. For a while, he lived somewhere in the East Coast. But he had a burning desire to get into New York and particularly to Harlem to see the American Blacks, then called Negroes, about whom he had heard a great deal.

The family took him to New York and as they drove around the streets of Harlem, he wondered where the Negroes were. His hosts drew his attention to the many people all over the area. "These!" remarked the Southerner. "But they are Arabs." And indeed the American Black looks very similar to the Northern Sudanese.

When the Sudan became independent, the South and North were almost alien parts of one country, which only agreed on getting rid of colonialism, but otherwise faced the dawn of independence with a political crisis that erupted into civil war. The example of the Sudan is striking not so much because of the many problems it has in common with Africa, as it is because of the remarkable model it offered Africa for the solution of similar problems and the unfortunate way these positive domestic achievements are being threatened by adverse external involvement. After seventeen years of an acute civil war that had devastated the country, crippled the economy, and 
brought the constitutional developments to a standstill, the government, under the leadership of President Nimeiry, was able to achieve peace through negotiations and dialogue, granting the South regional autonomy within the united Sudan. With this remarkable achievement, many other positive developments came in rapid succession. Sudanese were at long last able to agree on a permanent constitution. An ambitious programme of social and economic development, aimed at bridging preexisting gaps between South and North and between rural centres and urban centres, soon captured the imagination of the entire country and became a constructive replacement to the psychology of conflict. Development became an ideology or a strategy for reinforcing and consolidating the achieved peace and unity. Sudan's foreign policy and diplomacy were directed towards serving domestic purposes: soliciting foreign assistance in the monumental task of repatriating, resettling and rehabilitating the million returnees and displaced people in the South, and promoting international cooperation for the development of Sudan's vast resources in the mutual interest of all. Trilateral cooperation with Western technology and Arab financial contributions was envisaged to turn the Sudan into the bread basket of the Middle East.

In due course, the spirit of national reconciliation was extended to welcome back and integrate into the institutions of government those elements of the opposition abroad who had only a year before staged a bloody and costly invasion of Khartoum. Prisons were emptied of all political prisoners. Peace, unity, reconciliation, and development became the catch words. With the success of the Southern experience, Sudan extended the principle of regional autonomy to all parts of the country, thereby taking power to the people and involving them in their own government and development.

Over the years, Sudan won regional and international recognition as a country which had truly put its house in order. Bilateral agreements were concluded and joint committees established to ensure peaceful co-existence and cooperation with the neighbors. Morally strengthened by its domestic achievement, Sudan became a strong advocate of peaceful ways of resolving disputes, taking or supporting regional or international initiatives towards that end, presenting its own experience as a model which might be relevant to the solution 
of similar problems in the region, and on the whole, hoping that Sudan's domestic achievements might have positive ripples across its extensive borders into the neighboring countries.

Unfortunately, that did not prove to be the case. As tension and conflict pervaded the surrounding areas, as refugees poured into the Sudan in unprecedented numbers, as the borders became trouble spots, and as regional and international politics began to polarize countries, Sudan has increasingly become a target to adversaries operating within and abroad. The very size and composition of the country, the dualism of its ethnic and cultural identity, the multiplicity and diversity of its neighbors, and its overall geo-political position reflect potentials for both exciting opportunities and grave difficulties. I am reminded of a conversation I recently had with a colleague from an island country. After outlining the problems his country faces, he concluded with a positive note: "At least we do not have the problem of neighbors." One only has to glance at the trouble areas surrounding the Sudan to realize the magnitude of the problems facing the country. But the danger is more than potential for, at least on two occasions, the Sudan suffered severely from coup attempts that were inspired and supported by foreign powers. These past experiences, and the looming threats which have recently been the subject of wide international coverage, show the extent to which it is not enough to put one's house in order to ensure domestic security. The problem of security in Africa is local, regional and global and should be approached as such.

The problems of the Sudan have been aggravated by the world economic crisis, especially the balance of payment problems resulting from the oil-bills and other imports from industrial countries dictated by the immense development activity going on in the country. The very achievements of the government: autonomy in the South, ambitious development programmes, restructuring the country's political system, broadening national reconciliation, and the more recent extension of autonomy to the other parts of the country, all imply tremendous expenditure. Even being both Arab and African, discharging the obligations of that dual identity and the responsibilities of the international community, is a costly exercise.

Some people have chosen recently to focus on the poverty 
of the Sudan, wondering whether the slogans of the seventies that promised to turn the country into the bread-basket of the Middle East have vanished. The answer may not be simple. But other questions can be posed: Do not the 200 million acres of arable land and the vast animal wealth of some 60 million head on which the projections were based still exist in the Sudan!? And what of the additional resources that are increasingly beginning to surface, the oil reserves, the mineral wealth, and the untapped potentials of that vast land in the heart of Africa!? Short term needs resulting from the crisis situation and the impatience of financial institutions should not overshadow long term potentialities; otherwise, efforts to realize them might be undermined.

\section{New African Trends}

Despite some of the obstacles and external threats which have confronted and continue to face the Sudan, the experience of ending the dispute in the South has set a positive tone towards mediation, arbitration, and conciliation which the Organization of African Unity has recently moved to reinforce and strengthen. Africans are increasingly realizing that intra-African conflicts should be peacefully resolved through the Organization or at least with efforts at mediation by individual African leaders or groups of leaders. Committees were set up to work at resolving conflicts between a number of African countries and in some cases leaders took their own independent initiatives while keeping the organization informed, if not directly involved. Of course, the results have not always been as gratifying as the efforts, but this trend reflects the clear desire of Africa to minimize resort to force. As a consequence of this new trend, the Organization has recently been considering ways and means for revitalizing the Commission of Mediation, Conciliation and Arbitration provided for in the OAU Charter, but which has not been active in the past.

The emphasis on peaceful solutions to problems in today's Africa also poses issues of a cross-cultural conflict between the Western conceptions of power and diplomacy, which Africa has adopted and assimilated, and those of traditional Africa. It was Gunnar Jarring in a lecture delivered in Khartoum who told an animal story, the specific details of which I now 
forget, but the gist of which was to illustrate the principles of diplomacy. As the strongest animal posed the question of how they should share the prey before them, one rushed into a recklessly greedy answer and was immediately eliminated. The question was posed to the next. His answer was generous and selfless. "From where did you acquire this wisdom?" asked the master beast. The answer was: "I saw what you did to the other!" Ambassador Jarring called that primitive diplomacy.

Putting aside the precise meaning attached to the word "primitive," I responded by saying that it sounded to me more like what we faced in our modern world, orientated as we are to concepts of power that are based on police force and military might. This is the essence of the adversary and coercive character of Western jurisprudence, which contrasts quite sharply with the emphasis African concepts of law, and I might add diplomacy, place on persuasion and the spirit of mediation, conciliation and arbitration, far from any intimidation or threat, for that would negate the value and meaning of mediation and conciliation. It is therefore not by chance that the founders of the Organization of African Unity established a special commission to discharge these precise functions. As the need has intensified, so has the call for reviewing, adapting and activating this Commission to guarantee its relevancy and effectiveness. Nor need the functions of mediation and conciliation be viewed only in the context of inter-state relations, as media for harmonization: they can be exercised for the solution of domestic conflicts. Interference is the unwelcome involvement of outsiders; mediation, conciliation and arbitration signify positive cooperation.

\section{Conclusion}

I should perhaps conclude with a few observations emanating from what $I$ have said in the preceding remarks. First, I would like to underline the interrelationship of all levels of the African security scene: the local, the national, the regional and the international levels are all involved.

This being the case, while there is a great deal of truth in the argument that putting one's house in order is the best way of guaranteeing one's security, the involvement of others 
whether within Africa or from outside the continent, should not be taken lightly.

In considering the domestic, continental or international dimensions of the problem, efforts at defusing crises or conflicts through peaceful methods of dispute settlement should be the first priority and one that must be pursued with vigor and intensity.

It is particularly important that the outside world, and especially the powerful nations, view the cause of peace in global and comprehensive terms. In most cases, people hear of conflicts around the world as exciting news items, forgetting that they mean death and disaster to those involved. I recall in the sixties a prominent world religious leader declaring, "Let there be no more wars." And Vietnam was flaming with war. To some people, the world is at peace; to others, it is at war. It is indeed telling that some of the tribes of the Southern Sudan refer to the civil war days as the time when the world was destroyed.

The global view of peace means that big powers should not contend with negotiating matters of direct relevancy to the maintenance of peace between them while permitting and even inciting their confrontation through others on foreign soil. Peace everywhere should be the objective of negotiations anywhere.

One last but most important thought concerns the intellectual and scholastic tools of facilitating the cause of peace and security in Africa. As Africans have become active participants on the global scene, scholars can no longer afford to look on the African scene as an isolated frontier for field research, bearing little or no relevancy to the issues of global dimensions. Even what may seem culturally remote and exotic might explain the behavior patterns of African leaders or representatives who feel part of the modern world with an input that should not be ignored. Such slogans as Negritude, African Socialism, Authenticity or Humanism, espoused by African leaders, are philosophical formulations seeking to give a sense of cultural identity and substance to the aspirations of today's Africa. It is for the intellectual and the scholar to give depth and flesh to such skeleton conceptualizations in order to facilitate the realization 
of some of the values subsumed under the slogans.

One of the most challenging intellectual and diplomatic tasks in Africa is how to reconcile principles that now appear to be in conflict. In particular, the principle of maintaining the inherited boundaries needs to be reconciled with the right of self-determination by balancing national unity with the aspirations of minority groups for recognition and effective participation in their own government. While it is not easy to achieve a satisfactory balance, I know it can be done because it has been done; all the same grafting a model in a different context is no mean task but a challenging one.

Finally, and having taken as long as I have, I would like to end with a story I heard only recently about a Cabinet Minister. He was said to be so busy that he not only had his speeches prepared for him, but hardly ever had time to go over them before delivery. One time, he told his speech writer that the speeches were far too long. He had to cut them down to a fraction of the size. When the next occasion came, the Minister found himself reading a speech that seemed even longer than the former speeches. When it was over, he came to his speech writer and said, fuming with anger, "Did I not tell you to drastically cut down the length of the speeches!?" "That is exactly what I did," said the speech writer, "but then you read the three copies I gave you."

I hope I have not over-stated my points, whether by the length or by repetition. 
HANS WOLFF MEMORIAL LECTURES

1968 - Present

1968-69 David Dalby, University of London. United Kingdom. Linguistics. "Black through White: Patterns of Communication." (24 March 1969)

1969-70 Emile Snyder, University of Wisconsin. United States. African Literature. "Tradition and Modernism in African Literature." (4 March 1970)

1971-72 Wilfred H. Whiteley. University of London. United Kingdom. Linguistics and Anthropology. "To Plan is to Choose: The Rationale and Consequences of Language Choice in Eastern Africa." (7 April 1972)

1972-73 Anthony H.M. Kirk-Greene, St. Antony's College, Oxford University. United Kingdom. French, Political Science, and Anthropology. "Mutumin Kirkii: The Concept of the Good Man in Hausa." (11 April 1973)

1973-74 A.E. Meeussen. University of Leiden and Royal Museum of Brussels. Belgium. Linguistics. "Africanisms." (18 April 1974)

1974-75 Sembene, Ousmane. Senegal. Novelist and film-maker. "Man is Culture." (5 March 1975)

1975-76 A. Teixeira DaMota. Centro de Estudos de Cartografia Antiga, Lisbon. Portugal. History, Geography.

"Some Aspects of Portuguese Colonization and Maratime Trade in West Africa in the 15th and 16th Centuries." (5 March 1976)

1976-77 Nathan M. Shamuyarira, University of Dar es Salaam. Zimbabwe. Political Science and Journalism. "The Political and Economic Crisis in Southern Africa." (14 Apri1 1977)

1977-78 Batourou Sekou Kouyate, National Ensemble of Republic of Mali. Mali. Kora soloist. A concert of Mande poetry and song. (19 April 1978)

1978-79 L. Adele Jinadu, University of Lagos. Nigeria. Political Science. "Structure and Choice in African Politics." (5 April 1979)

1979-80 Leo Kuper, University of California-Los Angeles. South Africa. Sociology. "South Africa: Human Rights and Genocide." (18 April 1980)

Hilda Kuper, University of California-Los Angeles. South Africa. Anthropology. "Biography as Interpretation." (21 April 1980)

1980-81 Ruth Finnegan. Open University, Milton Keynes. United 
Kingdom. Folklore and Anthropology. "Short Time to Stay: Comments on Time, Literature and Oral Performance." (1 April 1981).

1981-82 Francis M. Deng, Ambassador from Sudan to Canada. Sudan. Law, Jurisprudence, and Anthropology. "Security Problems: an African Predicament." (23 October, 1981) 